\title{
LETTERS
}

Send your letters to the editor, British Dental

Journal, 64 Wimpole Street, London W1G 8YS

E-mailbdj@bda.org

Priority will be given to letters less than 500

words long. Authors must sign the letter,

which may be edited for reasons of space

\section{Clarification for carers}

Sir, I read Views and experiences of parents and siblings of adults with Down Syndrome regarding oral health care: a qualitative and quantitative study (BDJ 2005; 198: 571-578) with interest, and we agree that current policy initiatives provide an opportunity for dentists to collaborate with other health and social care professionals to improve the provision of oral health care for people with Down Syndrome and other learning difficulties.

However, a problem we still find occurring is that some social services carers will use the slightest sign of resistance on the part of their client to immediately terminate any attempt at tooth brushing or other oral care 'as to continue would be an assault on the client'. This is a scenario that we are sure many other readers are familiar with.

This can be immediately parried by reference to the document No Secrets, ${ }^{1}$ published by the Department of Health and the Home Office. Of particular note is section 2.7 which lists "neglect and acts of omission, including medical and physical care needs' as a form of abuse. Section 2.17 specifically refers to dentistry as an example of where failure to access key services is a form of abuse.

This document appears to be little known in dental circles; however it is a most useful one, as the attitude of carers changes immediately if it is pointed out that according to government guidelines, by failing to ensure good oral hygiene they are actually abusing their clients.

Copies are available from the Dept of Health, PO Box 777, London SE1 6XH or via the DoH website.

\section{Barber}

\section{K. I. Wilson}

\section{Sheffield}

1. No Secrets: Guidance on developing and implementing multi-agency policies and procedures to protect vulnerable adults from abuse. Department of Health, 2000.

doi: 10.1038/sj.bdj.4812657

\section{Oral lichenoid lesions}

Sir, in Oral lichenoid lesions related to dental restorative materials (BDJ 2005;
198: 361-366), the majority of patients with oral lichenoid lesions (54.9\%) and oral lichen planus (70\%) had one or more systemic problems (mentioned in Table 1). Drugs used for treatment of the majority of these systemic diseases have the potential to cause lichenoid lesions in the oral cavity. ${ }^{1}$ In some patients included in the study, lichenoid lesions were observed in the oral cavity at a site without any contact with the amalgam restorations. Are these lichenoid lesions due to systemic medications rather than amalgam restorations?

It is further mentioned in the article that in four patients the lesions resolved without any treatment. In another four patients there was no improvement even after replacing the restorations. These points raise further concerns about the possible cause of lichenoid lesions. Some studies use WHO criteria for diagnosis and distinction between OLL and OLP. ${ }^{2,3}$ Mentioning this as the inclusion criteria would have been more appropriate.

In Tables 5 and 6, it is mentioned that two patients had no lesions but were only symptomatic. I am interested to know how the diagnosis of lichenoid lesions was established in these two patients based on clinical symptoms only.

With regards to the special investigations, it would be interesting to know how estimation of serum ferritin, iron binding capacity and vitamin B etc were helpful in this study...?

It is suggested that immunofluorescence is a useful tool to differentiate between oral lichenoid lesions and oral lichen planus. ${ }^{4}$ This could have been a useful additional investigation in these patients.

\section{A. Auluck \\ K. M. Pai \\ By email}

1. Neville B W, Damm D D, Allen C M, Bouguot J E (eds). Allergies and immunologic diseases. In Oral and maxillofacial pathology (2nd Ed). pp 301. UK: WB Saunders, 2002.

2. Van der Meij E H, Schepman K P, Van der Waal I. The possible premalignant character of oral lichen planus and oral lichenoid lesions - A prospective study. Oral Surg Oral Med Oral Pathol Oral Radiol Endod 2003 96: 164-171.

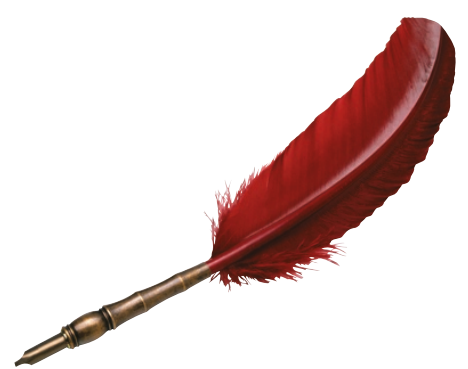

3. Kramer I R, Lucas R B, Pindborg J J, Sobin L H. Definition of leukoplakia and related lesions: An aid to studies on oral precancer. Oral Surg Oral Med Oral Pathol 1978: 46: 518-539.

4. Raghu A R, Nirmala N R, Sreekumaran N. Direct immunofluorescence in oral lichen planus and oral lichenoid reactions. Quint Int 2002; 33: 234-239.

doi: $10.1038 /$ sj.bdj.4812658

\section{Food labelling}

Sir, while we welcome the demise of the BDA's accreditation system - which inevitably led to a perception of our association being compromised, we were keen to highlight our concerns which have followed from the 'Ribena Toothkind' debate.

We are more than a little disappointed to witness the latest efforts made by GlaxoSmithKline (GSK) to market Ribena to consumers. It would seem that while 'Ribena Toothkind' is no more, our interpretation this time would seem to be that GSK's latest effort is being blatantly targeted specifically at babies and toddlers. The drink is branded as 'really light' and carries the banner 'friendly to teeth', although there is not a shred of evidence to support this latter claim. Unfortunately, it gets worse - the bottle is shaped tantalisingly like a child's feeding bottle! The manufacturers clearly aim to redeem themselves by claiming on the reverse of the bottle (in much smaller writing): 'Neither this drink nor cap is suitable for babies and toddlers under 36 months'.

Clearly, there are important public health issues at stake here. The BDA ought to be leading this debate - around clear/consistent food labelling and marketing of food/drink to children.

\section{S. Creanor \\ D. Conway \\ Glasgow}

doi: 10.1038/sj.bdj.4812659

\section{Controversial claims}

Sir, oral health won a significant victory recently ... though it might not seem that way to the BDA.

'Ribena Toothkind' (RTK), the children's drink that claimed it 'does not encourage tooth decay' has been withdrawn, replaced with 'Ribena Really Light', a low 
calorie liquid targeted at young women. In 1998, the BDA 'accredited' RTK's claim; the first time it had ever allowed the association's name on a drink. Action and Information on Sugars, of which I was then Chairman, complained to the Advertising Standards Authority, based on proof of the product's cariogenicity from the Zurich Dental School. After two and a half years of acrimonious exchanges and threats, the High Court upheld the complaint: RTK's claim was misleading. Simultaneously, the BDA's accreditation was discredited.

For GlaxoSmithKline, maker of Ribena, the consequences of the false claim have been severe: public shame, falling sales and now withdrawal; all the research and promotional expenditure wasted. Commercially, they are back to square one, with a different product, for different consumers, making different claims. They paid a high price for their hype.

But the effects for oral health are much more positive. If the first exaggerated claim for dental safety on a drink had got through, it would have opened the floodgates for other excesses. Instead, the RTK affair has effectively established very high standards for dental claims by foods and drinks.

Other companies that were preparing 'safety' claims for drinks have dropped the plans, prudently avoiding the costs and humiliation of Ribena's hubris. The moral of the story is: if you make a claim, it had better be true.

This is crucial for the future. Many new 'functional foods' with added ingredients promising oral health benefits are under development. Companies are experimenting with new sweeteners, minerals, peptides, polyphenols, antibody fragments, even 'healthy' bacteria.

Not all will overcome the research hurdle, but some will. When they come to market they will be promoted with claims communicating their dental effects. As a result of the RTK case, there is greater likelihood these claims will be true. Dental professionals and consumers alike may have greater confidence in the new products. As a result, oral health may improve.

That is the long term promise of the embarrassing short term controversy over Ribena Toothkind.

\section{J. T. Winkler \\ Food and Health Research \\ By email}

doi: $10.1038 /$ sj.bdj.4812660

\section{Philosophy in practice}

Sir, there is much talk about the proposed new contract, and its ability to remove the dentist from the 'treadmill' of NHS dental care. Unfortunately, there is one small problem here. The treadmill is not a problem with the NHS system; it is a problem with how the dentist works within the NHS system. Let me try and explain my reasoning.

Many clinicians have proven that by spending more time with patients, you can build rapport and trust. By doing this, you can then highlight the treatment that the patient actually wants, instead of the dentist deciding what treatment the patient needs. Through co-diagnosis, the clinician and the patient can form a mutually acceptable decision on which treatment option is best for the patient. When the patient understands the quality options, they often choose to have their treatment done outside the NHS fee scale. So long as the patient completely understands that this treatment is private, and so long as the correct terms of service are applied, this can be a very ethical and lucrative way of running an NHS practice, with good cash flow and a reasonable wait for an appointment time. This also allows the practice to keep patient numbers at a manageable level, concentrating on a core dental base of patients that the dental staff like and respect. In return the patients like and respect the dental staff, which greatly reduces patient complaints and litigation, violence and abuse, DNAs and late cancellations, and late and outstanding payments.

The problem, it seems, is that many NHS dentists think they have to be busy, busy, busy to make a living. They think that they have to have 6,000 patients on their list to receive the capitation payments, and that they should be booked three months in advance. They often feel the need to see over 40 patients a day and work six days a week. The fear of the low fee scale makes most dentists think they have to cram masses of treatment into the working day, instead of taking the time out to run their business like a business. This is the model that creates the treadmill, sleepless nights and bad health.

The New Contract and PDS will not be a cure for the treadmill. If the practitioner does not change his or her philosophy of how they practise dentistry, they will simply replace one type of treadmill for another. The need to do ' $\mathrm{X}$ ' number of DENTOs and keep the gross fees collected at a certain level will keep the practitioner working at exactly the same pace (if not faster) ... unless they act now to change the way they work. I think this needed to be said, and I appreciate that many out there will totally disagree with me. To those individuals I ask a simple question: 'Are you enjoying being a dentist?'

\author{
S. Hudson \\ By email \\ doi: 10.1038/sj.bdj.4812661
}

